\title{
Basics of Anatomy and Physiology of Cornea
}

\section{Dr Partha Haradhan Chowdhury ${ }^{1 *}$ and Brinda Haren Shah ${ }^{2}$}

1Ph.D. in Optometry (Gujarat State Government University) and Professor and Principal, Shree Satchandi Jankalyan Samiti Eye Institute - Pauri, Uttarakhand, India

${ }^{2}$ M. OPTOM, Practitioner, Ahmedabad, Gujarat, India

*Corresponding Author: Dr Partha Haradhan Chowdhury, Ph.D. in Optometry (Gujarat State Government University) and Professor and Principal, Shree Satchandi Jankalyan Samiti Eye Institute - Pauri, Uttarakhand, India.
Received: March 23, 2021

Published: April 15, 2021

(C) All rights are reserved by Dr Partha

Haradhan Chowdhury and Brinda Haren

Shah.

\section{Abstract}

This paper describes about basic details on anatomy and physiology of cornea.

Keywords: Anatomy; Physiology; Cornea

\section{Introduction}

Cornea is a transparent, avascular, aspheric structure of the eyeball. It is centrally steep and peripherally flat. It consists of $1 / 6^{\text {th }}$ of the fibrous coat of the eyeball. Some amount of vascularization is present at the peripheral part of the cornea.

Corneal curvature plays an important role for the refraction. Always it is remembered that above the cornea, tear film plays an important role for refraction during contact lens fitting.

Cornea is centrally thin $(0.52 \mathrm{~mm})$ compared to periphery $(0.67$ $\mathrm{mm})$. Central portion of the cornea $(5 \mathrm{~mm})$ is responsible for the refractive zone. Anterior radius of curvature is $7.8 \mathrm{~mm}$ and posterior radius of curvature is $6.5 \mathrm{~mm}$.

For the refraction, cornea is responsible for $3 / 4^{\text {th }}$ of the eyeball. It means:

$\mathrm{C}=(60 * 3 / 4)=45.00 \mathrm{D}$.

Refractive index of cornea is 1.37 .

Layers of cornea:

- Epithelium

- Bowman's membrane
- Stroma

- Descemet's membrane

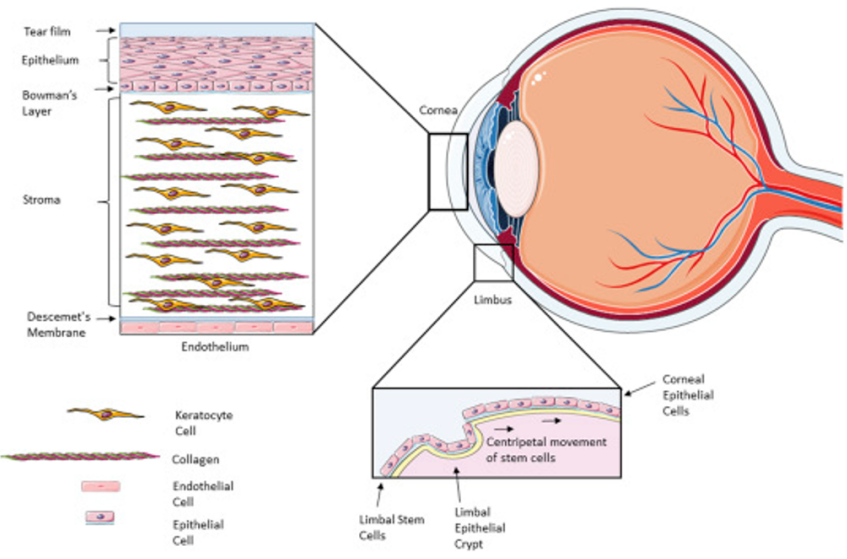

Figure 1

\section{Epithelium}

It is the super most layer of the cornea. It is a regenerative layer. Epithelium is about 50 to $60 \mu \mathrm{m}$ thick and it consist of three layers: 
1. Squamous cell layer

2. Wing cell layer

3. Basal cell layer.

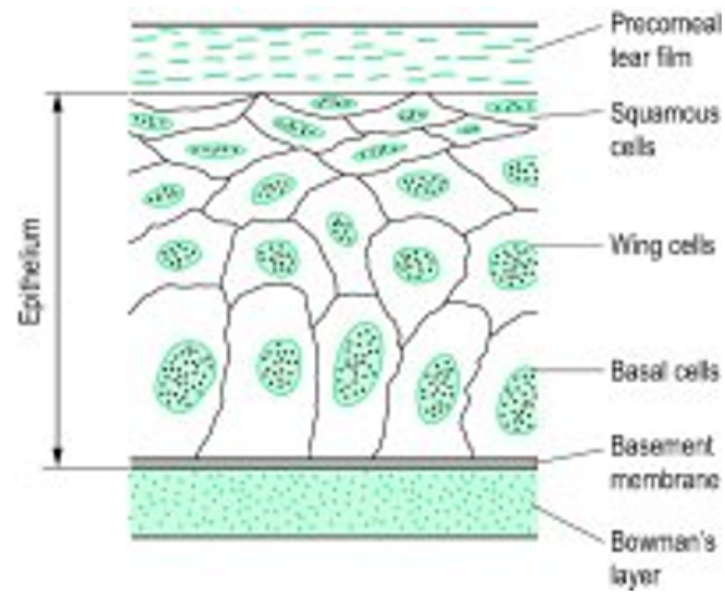

Figure 2

Bowman's membrane

It consists of acellular mass. If it is damaged then it does not regenerate. It shows considerable resistance from injury.

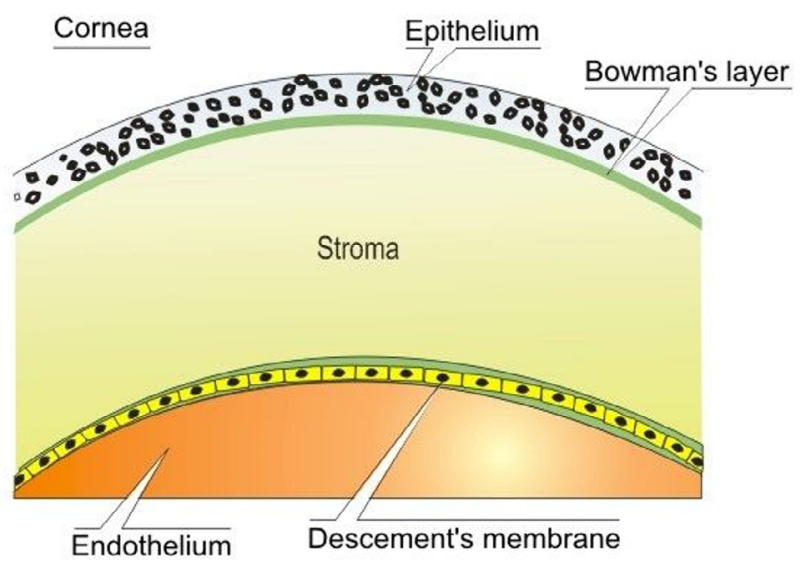

Stroma

It is the thickest layer of the cornea. It is usually $0.5 \mathrm{~mm}$ thick. It consists of collagen fibrils and it consist of 200 - 300 layers.

\section{Descemet's membrane}

It is a homogenous layer and bound to stroma posteriorly. Its thickness increases with age. It is made up of collagen and glycoprotein, no elastic materials are present. It is strongly resistance to trauma, foreign body etc. It can regenerate after damage.

\section{Endothelium}

It consists of single cell layer. Each cell is Hexagonal in shape. As age increases the number of cells decreases. These cells once damaged will not regenerate [1-3].

\section{Bibliography}

1. AK Khurana and Indu Khurana. "Anatomy and Physiology of Eye". $3^{\text {rd }}$ Edition (2017).

2. AK Khurana. "Disorders of Cornea and Ocular Surface". $1^{\text {st }}$ Edition (2020).

3. Darlene Dartt., et al. "Encyclopedia of the Eye". $1^{\text {st }}$ Edition (2010).

\section{Assets from publication with us}

- Prompt Acknowledgement after receiving the article

- Thorough Double blinded peer review

- Rapid Publication

- Issue of Publication Certificate

- High visibility of your Published work

Website: www.actascientific.com/

Submit Article: www.actascientific.com/submission.php Email us: editor@actascientific.com

Contact us: +919182824667

Figure 3 